\title{
A Review of Uncovered Myriad Inequities within Systems of Education Amidst Covid-19
}

\author{
Natalia S. Intja ${ }^{1}$, Kretha Mbambo $^{2}$, Martha Nahole ${ }^{3}$ \\ ${ }^{1}$ Lecturer in the Faculty of Education and Human Sciences, Department of Intermediate and Vocational Education, University \\ of Namibia's Rundu Campus \\ (nreino@unam.na) \\ ${ }^{2}$ Lecturer in the Faculty of Economics and Management Sciences, University of Namibia Rundu Campus \\ ${ }^{3}$ Lecturer in the Faculty of Education and Human Sciences, Department of Intermediate and Vocational Education, University \\ of Namibia's Rundu Campus
}

Abstract

This study aims at revealing how the Covid-19 pandemic has degraded the inequities in the education fraternity by looking at how children and families access resources, whether or not they have supportive and safe environments that are necessary for optimal learning knowing that inequities are exponentially greater in times of crisis and suggest strategies to unravel the inequities to advocate for equal distribution and access of needs for all in academia. Literature was reviewed and analyzed by searching the Google Scholar database. The following keywords were used in the search: Covid-19, educational inequities, education, horizontal and vertical equities, and myriad. The study revealed that family crises, lack of healthcare, mental health issues, poor technological instructions such as internet connectivity and computers, and poverty are one of the many challenges of educational inequities signaling as constraints to online learning in the Covid-19 pandemic. The study recommends the government partner with Internet Service Providers (ISPs) to install VSATs at the unreached areas, the government can advise or encourage the mobile network operators that is MTC and Telecom to extend their coverage (which must include $3 \mathrm{G}$ and $4 \mathrm{G}$ ) to remote areas, the government should fund a one-home-one-device initiative. This is to ensure that every home has access to an internet-enabled device and the schools should also devise the strategies of innovating, sustain and optimizing to unravel the inequities in academia.

Keywords: Covid-19; Educational Inequities; Education; Horizontal; Vertical Equities; Myriad

\section{Introduction}

Covid-19 has led to precarious circumstances wherever holding a way of normality for learners and their academics are crucial. Given the unprecedented closure of learning establishments, one in every of the foremost pressing tasks facing educators is to make sure that students' learning is uninterrupted. within the 
same line of thought, UNESCO (2020) maintains that making certain that learning isn't at a halt is preponderating. Yet, specializing in the never-stopping half alone, as if it does not have an effect on everything else regarding the aim and also the worth of schooling, is quite slim associated would possibly provide the talk an air of deceptive simplicity. It ought to once more be noted that quality learning prevails. This task is additional imperative, despite that the education realm is already faced with its bigger crisis that is that the international learning crisis that's being modified by the Covid-19 pandemic. Moreover, the complete education scene has begun to look surreal: faculties are motility doors, and oldsters and caregivers are scrambling to home college their kids and to appear for tactics to stay them engaged. where doable, a stronger engagement with remote learning has taken place.

In addition, the education fraternity didn't signal the various changes the pandemic would wake education and learning. And it's onerous to scale and vary what's to emerge (Popa, 2020). However, the planet Economic Forum (2019) notes that to know the complexness of the changes ahead, we'd like to be acutely aware of the history of our time in terms of the manageable, overwhelming reality of what's to be done.

In this study, myriads of inequities among the education systems square measure unconcealed regarding the Covid-19 pandemic. A study conducted by Ismail (2015) regarding equity and education alludes that equity and education square measure long-standing goals of the many societies and their square measure numerous views on ways in which to supply equal opportunities and resources for all. She defines equity as fairness, disposition, and justice and is expounded to equal opportunities. additionally, she still contends that equity in education is typically connected to equal access to formal education opportunities and resources. within the same line of thought, Chu (2019) in his study regarding "What square measure they talking regarding after they say Equity?' A Content analysis of equity principles and provisions in State each Student Succeeds Act Plan" outline equity in education as equity in access to instructional resources like funding and educators. Baker and inexperienced (2015) outline equity in education as "primarily variations or relative variations in instructional resources, processes, and outcomes across children” (p.231). during a similar nonetheless additional careful approach, Cook-Harvey, Darling-Hammond, Lam, Mercer, associated mythical creature (2016) outline equity as "policies and practices that give each student access to an education targeted on purposeful learning skills up to date society needs in ways in which empower students to be told severally throughout their lives" (p.1). Cook-Harvey, et.al., (2016) contend that associate just education needs competent and caring educators World Health Organization square measure supported by adequate resources in order that every student will develop his or her full tutorial and social potential. Knight $(2017,2019)$ reports 
that faculties serving high impoverishment and high minority students on the average receive less funding. Verstegen (2015) emphasizes that equity specializing in providing equal opportunities for all kids to be told ought to be upheld.

This paper adopted the definition of Ismail (2015) that states that equity refers to equal access to opportunities and resources for all. In lightweight of this definition, one might deduce that each one learners should be accorded equal access to check materials, causative learning environments, adjuvant and safe environments that square measure necessary for optimum learning, being tutored by old and extremely qualified teachers/ educators and through the Covid-19 pandemic wherever most of learning and teaching is going down within the virtual house, students have access to uninterrupted net property and that they have laptops or computers to access the web learning platforms, write tests, examinations and concerned in on-line discussion forums.

\section{Literature Review}

2.1. Understanding the Two Types of Economic Equity (Horizontal equity versus Vertical equity)

\subsubsection{Horizontal Equity in Education}

Soika (n.d) defines horizontal equity as a situation during which each student receives an equivalent resource, no matter wants.

\subsubsection{Vertical Equity in Education}

This is an additional dynamic approach to equity during which faculties give additional support for college students World Health Organization lack the resources of alternative students. for instance, kids World Health Organization belong to a low-income family on food stamps face further barriers to tutorial action and might have the benefit of further resources (Soika, n.d).

\subsection{Benefits of Focusing on Equity in Education}

Equity in faculties is that the answer to supporting each student, not simply those from deprived backgrounds. once faculties give their students with resources that match individual circumstances, the complete room atmosphere improves (OECD Observer workers, 2008). Not solely that, however the importance of equity extends to our society as a full. unjust communities, everybody has the chance to succeed no matter their original circumstances. 
Gorard and Smith (2004) underscore that on a surface level, the advantages of comprehensive and just school rooms reach tutorial action. faculties with the tiniest action gaps between demographics have the very best overall take a look at scores. this suggests that once the foremost deprived student scores improve, students from additional privileged backgrounds improve, too. once faculties square measure aware of various backgrounds and supply the proper resources, all students square measure ready to be told and facilitate one another succeed.

Atchison, Diffey, Rafa, and Sarubbi (2017) contend that equity may strengthen a student's health and social-emotional development. during a study involving over four,300 students in Southern California, the kids World Health Organization felt safer, less lonely, and reportable less bullying conjointly had higher diversity levels in their categories. Being equipped to push diversity and supply for college students from all backgrounds makes for associate atmosphere wherever students feel comfy and have higher emotional regulation. in addition, just communities square measure connected to higher health and longer average lifespans. (OECD Observer workers, 2008) note that encompassing communities have the benefit of the equity in faculties similarly. Equity is connected to stronger social cohesion, which means that people connect with one another higher and square measure additional compassionate. It conjointly results in long economic process. this suggests that promoting equity in faculties may be one in every of handiest $\}$ and most effective social investments.

\subsection{Strategies to unravel inequities in academia}

Huber (2021) underscores that practices in the classroom, on the school level, and even on system-level vary and that is why the strategy that could and should be applied on all these levels should take this into account. Depending on the development stage of the school, the school development efforts must thus be weighed differently based on the available resources (Huber 2019, 2020). A school that is already successfully integrating digitalization will focus its efforts on sustainability and thus on preserving, and will carry out smaller innovations. A school that is still in its infancy in that regard will have to focus on innovation. Different weighting will thus lead to different strategies (Fig. 1). 


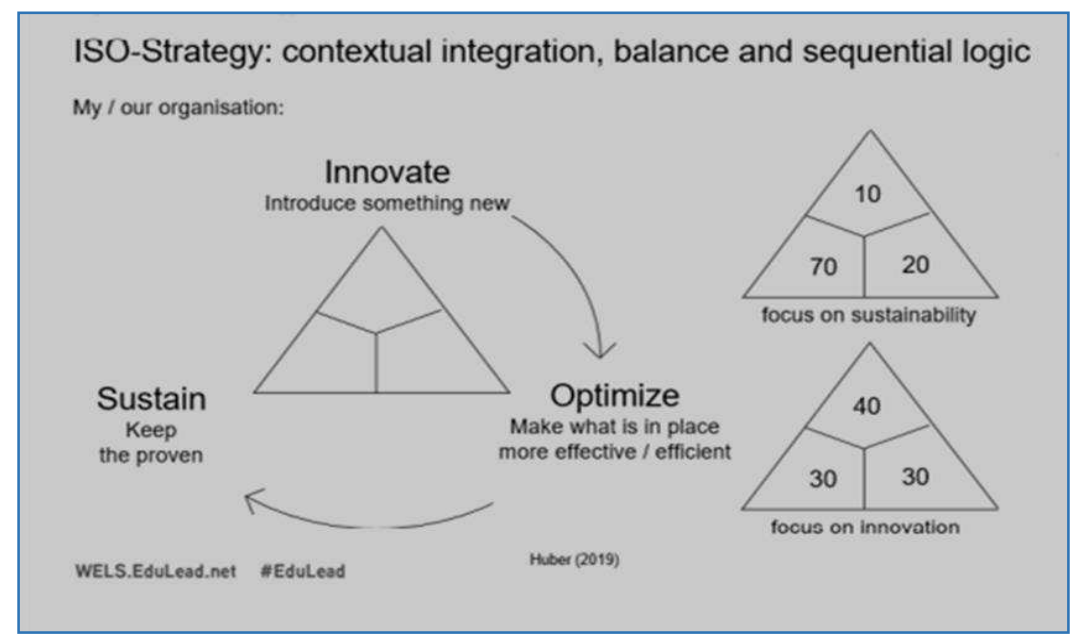

Fig. 1. Innovate, Sustain and optimize Strategies espoused from Huber (2021)

This figure entails that when a certain school found itself in the catastrophe of inequities due to the pandemic, the school management may look at what they have in place to ensure that their stakeholders (learners, staffs, and parents) remain resilient and positive about their learning and teaching. The management can evaluate and see that if their learners have computers or laptops in their homes to access lessons remotely then they will focus on sustaining what they already have and ensuring that the materials are being used to the benefit of all. And if the school does not have laptops, internet connectivity, or expertise, the staff should impose innovative ideas to ensure that learning and teaching do not stop despite the changes brought by the pandemic.

\section{Methods}

This study adopted a literature review method using a comprehensive strategy of searching for articles in the Google Scholar database from 2019 to 2021. It is worth noting that these are the years in which Covid-19 was first traced and hit the world which in return affected how schools operate. The following keywords were used in the search: Covid-19, educational inequities, education, systems, digital poverty, and myriad. Twelve (12) articles were obtained from the searched database and only six were analyzed due to their relevance to this paper and the aim of the paper. The articles were analyzed using the following headings, author (s) and year of publication, the title of the research, place or country of publication, name of the database, sample, study design, and the result of each article. 
The results of the research used in this literature review are as follows:

Table 1. Review of Research Results

\begin{tabular}{|c|c|c|c|c|c|c|}
\hline $\begin{array}{c}\text { Author (s) and Year } \\
\text { of } \\
\text { Publication }\end{array}$ & Title of the Research & $\begin{array}{l}\text { Place or country } \\
\text { of Publication }\end{array}$ & Database & Sample & $\begin{array}{l}\text { Study } \\
\text { Design }\end{array}$ & Results \\
\hline Chu (2019) & $\begin{array}{l}\text { What are they talking } \\
\text { about when they talk } \\
\text { about equity? A content } \\
\text { analysis of equity } \\
\text { principles and provisions } \\
\text { in state Every Student } \\
\text { Succeeds Act plans }\end{array}$ & United States of America & $\begin{array}{l}\text { Google } \\
\text { Scholar }\end{array}$ & $\begin{array}{l}52 \text { approved ESSA } \\
\text { plans from all } 50 \\
\text { states and D.C. and } \\
\text { P.R. and the } \\
\text { original ESSA } \\
\text { policy documents } \\
\text { from US DoE were } \\
\text { included for } \\
\text { contextual } \\
\text { information }\end{array}$ & $\begin{array}{l}\text { Qualitative } \\
\text { design }\end{array}$ & $\begin{array}{l}\text { The study reve } \\
\text { that every and e } \\
\text { required resourc } \\
\text { spite of their } \\
\text { gender, sexual } \\
\text { home language, } \\
\text { The study additi } \\
\text { learning setting } \\
\text { initiated Associa } \\
\text { ought to be desis } \\
\text { learning setting } \\
\text { services and } \\
\text { information } \\
\text { technology, an } \\
\text { discipline practic } \\
\text { instructional tec } \\
\text { distance or } \mathrm{v} \\
\text { mentioned in } \mathrm{n} \\
\text { method to offset } \\
\text { to effective lectu } \\
\text { high-minority } \\
\text { development for } \\
\text { students' access } \\
\text { learning mat } \\
\text { attainment. diffe } \\
\text { in Nursing servi } \\
\text { essential to pror } \\
\text { setting enclosed }\end{array}$ \\
\hline
\end{tabular}




\begin{tabular}{|c|c|c|c|c|c|c|}
\hline & & & & & & $\begin{array}{l}\text { rigorous course } \\
\text { access \{to colleg } \\
\text { school library } \\
\text { school message } \\
\text { access to the } \\
\text { college message } \\
\text { students for } \\
\text { discipline prac } \\
\text { proportionate } \\
\text { additionally as } \\
\text { specific teams, } \\
\text { extracurricular } \\
\text { learners and p } \\
\text { programs. }\end{array}$ \\
\hline Pollock (2020) & $\begin{array}{l}\text { School Leaders' Work } \\
\text { During the COVID-19 } \\
\text { Pandemic: A Two- } \\
\text { Pronged Approach }\end{array}$ & Canada & $\begin{array}{l}\text { Google } \\
\text { Scholar }\end{array}$ & School Principals & $\begin{array}{l}\text { Case } \\
\text { Study }\end{array}$ & $\begin{array}{l}\text { The pandemic } \\
\text { silo. The pander } \\
\text { of the unresol } \\
\text { public education } \\
\text { general) to the } \\
\text { indicated within } \\
\text { session that } \\
\text { concerning h } \\
\text { inequities were } \\
\text { new problems } \\
\text { access to quality } \\
\text { students and fog } \\
\text { students don't po } \\
\text { participate in o } \\
\text { might have the } \\
\text { wherever they } \\
\text { accessible LAN. } \\
\text { the required nec } \\
\text { physical area } \\
\text { active learning. } \\
\text { also disproport } \\
\text { COVID-19 as a } \\
\text { unit essential en } \\
\text { of they need }\end{array}$ \\
\hline
\end{tabular}




\begin{tabular}{|c|c|c|c|c|c|c|}
\hline & & & & & & $\begin{array}{l}\text { myriad of con } \\
\text { influence their } \\
\text { throughout the } \\
\text { area unit being } \\
\text { these problems. }\end{array}$ \\
\hline Martinez, et.al., (2021) & $\begin{array}{l}\text { Pencils Down: Educators } \\
\text { Respond to the } \\
\text { Uncertainty Amidst } \\
\text { COVID-19 School } \\
\text { Closures }\end{array}$ & $\begin{array}{l}\text { Knoxville, Tennessee, United } \\
\text { States }\end{array}$ & $\begin{array}{l}\text { Google } \\
\text { Scholar }\end{array}$ & $\begin{array}{l}\text { Nineteen teachers } \\
\text { and seven } \\
\text { administrators were } \\
\text { surveyed and } \\
\text { interviewed to gain } \\
\text { an understanding of } \\
\text { the effect of the } \\
\text { global pandemic on } \\
\text { their professional } \\
\text { lives. }\end{array}$ & $\begin{array}{l}\text { mixed } \\
\text { methods } \\
\text { study }\end{array}$ & $\begin{array}{l}\text { Eighty-five } \% \text { of } \\
\text { documented the } \\
\text { technology (i.e. } \\
\text { connectivity) to } \\
\text { communications } \\
\text { education. }\end{array}$ \\
\hline Ugwu (2021) & $\begin{array}{l}\text { E-Option for Health } \\
\text { Education Amidst } \\
\text { COVID-19: An } \\
\text { Examination of Somalia } \\
\text { Contexts }\end{array}$ & Nigeria & $\begin{array}{l}\text { Google } \\
\text { Scholar }\end{array}$ & $\begin{array}{l}\text { homebound } \\
\text { students }\end{array}$ & $\begin{array}{l}\text { Qualitative } \\
\text { Design }\end{array}$ & $\begin{array}{l}\text { With the pandem } \\
\text { Somali kids' } \\
\text { homebound as t } \\
\text { type of learnin } \\
\text { year. Poor elect } \\
\text { were the key } \\
\text { learning }\end{array}$ \\
\hline Huber (2021) & $\begin{array}{l}\text { Schooling and Education } \\
\text { in Times of the COVID- } \\
19 \text { Pandemic: Food for } \\
\text { Thought and Reflection } \\
\text { Derived From Results of } \\
\text { the School Barometer in } \\
\text { Germany, Austria and } \\
\text { Switzerland }\end{array}$ & Switzerland & $\begin{array}{l}\text { Google } \\
\text { Scholar }\end{array}$ & $\begin{array}{l}\text { around } 24,000 \\
\text { students, parents, } \\
\text { school staff, school } \\
\text { leaders, school } \\
\text { authority and } \\
\text { system support } \\
\text { personnel were } \\
\text { surveyed }\end{array}$ & Survey & $\begin{array}{l}\text { Differences in } \\
\text { become additiol } \\
\text { they're going to } \\
\text { least bit levels/a } \\
\text { students, the le } \\
\text { room and in fact } \\
\text { a tendency to arg } \\
\text { merely deed inf } \\
\text { it's additic } \\
\text { psychological fo } \\
\text { emotional aspec }\end{array}$ \\
\hline
\end{tabular}




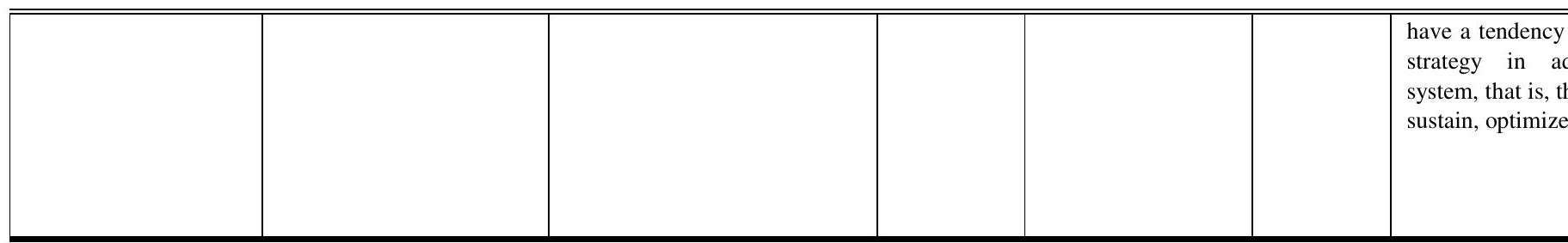




\section{Discussion}

Equitable learning atmosphere State plans ought to be initiated and programs ought to be designed to ascertain an equitable learning atmosphere by rising faculty services and facilities, as well as syllabus programs, library, technology, and guidance services, discipline practices, and faculty climate. instructional technological tools, like distance or virtual learning, were mentioned in many state plans as a way to offset the inequitable access to effective academics in high-poverty and high-minority districts, give skilled development for educators, and improve students' access to high-quality digital learning materials and digital accomplishment. alternative programs and services known by states as essential to promoting an equitable learning atmosphere enclosed "equitable access to rigorous courses for all students, equitable access to faculty to high school to high school library programs; "strategic school guidance to supply equitable student access to the total curriculum" and faculty guidance programs getting ready students for faculty and career; discipline practices "equitable and proportionate to the incident; additionally as services targeting specific teams, like syllabus and extracurricular programs for English learners and precocious course and programs.

An assessment of state consolidated ESSA plans disclosed that the bulk of the state plans adopted a foothold on equity accentuation access to learning opportunities as well as financial resources and high-quality educators, with a smaller range of state plans taking note to equity in outcomes. Consequently, the ways projected by states to handle the equity gaps centered on developing a lot of equitable funding formulas and manufacturing and putting knowledgeable and effective academics and leaders in school rooms and colleges so as to scale back the resource and chance disparities among districts and therefore the students they serve. Meanwhile, the answerability policies enclosed within the ESSA plans irresistibly centered on outcomes wherever educators were command in charge of manufacturing state-mandated results, like student accomplishment and growth scores and graduation rate, because the primary indicators of equity policy impact. The apparent pair between access-oriented equity policies and therefore the outcome-driven answerability systems could also be attributed to the underlying assumption that after instructional resources and opportunities are equitably distributed across districts and colleges, equity in learning outcome within the type of adequate student assessment performance are going to be achieved.

Even before the pandemic, Somalia was thought to be one in all the foremost acute within the world in terms of education deficit (African instructional Trust 2020). thanks to decades of war, terrorism, and financial condition, the scholars were forced to abandon their schooling (UNICEF 2019). With the pandemic around, extra several Somali youngsters are created homebound as they lose access to any variety of learning coupled with finishing their school year (Mwanjisi 2020). This condition has systematically exposed the kids to the 
violence of all kinds. in line with UN agency (2020), the kid Protection Agencies (CPAs) in Somalia have reported an identical rise in violence against youngsters. as an example, forty-one $\%$ of free youngsters are featured with raised vulnerability to conflict and sexual and economic exploitation (UNICEF 2020).

Somalia is at very cheap within the international league of net access (Mumin, 2018). Fuku and Hirsi (2018) ascertained that Somalia has very cheap net penetration rate within the world. solely $\{100 \mathrm{pc}|100 \%| 100$ $\%$ \} of her population has access to the web (Fuku \& Husseini a pair of020) with fewer than 2 percent of its folks often on-line (Mumin 2018). folks would need to jaunt the cities to access the web wherever coverage still remains uneven, expensive, and unpredictable even within the capital town of national capital (Mumin 2018). To worsen it all, Al-Shabaab Moslem militant cluster has forced the closure of net services in several areas of the country (Business Wire 2019). This portrays Somalia because the worst place for net activities notably with restricted ICT devices even in its colleges.

The provision of ICT infrastructures was chiefly for chosen colleges within the massive cities. Farrell, Isaacs, and Trucano (2007) as cited in Ugwu (2021) ascertained ICT devices are of restricted access and use in rural areas. Few of those found in secondary colleges were for the needs of administration and not for education (Omer et al. 2015). this can be not to mention a scarcity of trained academics (UNICEF 2020). All of those limit development of the ICT skills needed for e-learning among the scholars. as an example, in a very study conducted to look at the novice users' experiences of e-learning in Somalia, Omer et al. (2015) reported that lack of pc skills was among the main challenges knowledgeable by the novice users of elearning.

Lighting Africa (2020) reported that Somalia doesn't have a central electricity grid and higher than seventy $\%$ of its population lives while not electricity. The remaining thirty $\%$ of Somalis are served by in camera owned diesel-powered mini-grids, that they pay among the very best rates within the world, the report value-added. the purpose is: while not electricity, academics and students cannot power their devices, coupled with have access to the web.

In this literature, analysis conducted by Chu (2019) unconcealed that equity suggests that every and each learner receives the required resources they have to thrive in spite of their national origin, race, gender, sexual orientation, disability, home language, or family financial gain. The study additionally reveals that just learning setting State plans ought to be initiated Associate in Nursing programs ought to be designed to 
ascertain a just learning setting by rising college services and facilities, together with course of study programs, library, technology, and message services, discipline practices, and college climate. academic technological tools, like distance or virtual learning, were mentioned in many state plans as a way to offset the inequitable access to effective lecturers in high-poverty and high-minority districts, give skilled development for educators, and improve students' access to high-quality digital learning materials and digital acquirement. alternative programs Associate in Nursing services known by states as essential to promoting an just learning setting enclosed "equitable access to rigorous courses for all students, just access to college to high school to high school library programs; "strategic school message to supply just student access to the total curriculum" and college message programs getting ready students for faculty and career; discipline practices "equitable and proportionate to the incident; further as services targeting specific teams, like course of study and extracurricular programs for English learners and precocious course and programs. Deducing from this study and synthesizing it with the aim of this paper of uncovering the inequities within the education systems throughout the covid-19 pandemic, we are able to note that for on-line categories to be run swimmingly the challenges of web property for each learners and lecturers ought to be solved. As of current not all faculties in South West Africa have access to smart quality web property and as a result, some learners and students don't attend categories concerning \} that brings about the digital divide and also the issue of digital impoverishment to continue.

A different study by Pollock (2020) that was conducted in Canada concurs with Chung (2019) and exposes that the pandemic has brought several of the unresolved inequities in our public education systems (and society in general) to the forefront. Principals indicated within the virtual focus cluster session that they were involved regarding however pre-existing inequities were being exacerbated and new problems were arising around access to quality education for college kids and oldsters. for instance, some students don't possess the technology to participate in on-line learning. Others might have the technology, however wherever they live doesn't have accessible WLAN. Still, others might have the required necessities however not the physical area that's contributing to active learning. alternative students could also be disproportionately plagued by COVID-19 as a result of members of the family are essential staff, or as a result of they need unwell members of the family or a myriad of complicated factors that influence their ability to find out throughout the pandemic. Principals are being asked to assist address these problems. This entails that heaps must be resolved within the education systems to confirm that each lecturers and learners thrive in on-line teaching and learning despite the pandemic. as a result of some learners might need technological tools like 
computers and laptops that they'll partially use to access on-line categories however they could not have Wi-Fi property.

In addition, a study conducted by Martinez and Broemmel (2021) the United States disclosures that eighty-five percent of lecturers and directors documented the importance of tutorial technology (i.e. computers and web connectivity) to access content and communications associated with their education. In alternative words, lecturers and directors of faculties within the study see the importance of computers and web property to navigate during this error of the pandemic. Moreover, Ugwu (2021) in his study conducted in Nigeria posits that with the pandemic around, extra many Somali kids are created homebound as they lose access to any type of learning in addition to finishing their school year. Poor electricity and web services were the key constraints against e-learning. during this study, \{we can we interpret that poor electricity and web services are major constraints for learners to attend e-learning.

A study conducted by Huber (2021) mentions that "differences in quality won't solely become additional apparent, however they're going to increase over time, in any respect levels/among all actors: among students, the lecturers or within the room and in faculties as an entire. we tend to argue that learning is quite merely feat info and learning lessons. it's additionally regarding psychological feature and, above all, emotional aspects. wanting ahead, we tend to promote a particular strategy in advancing the college system, that is, the ISO strategy: introduce, sustain, optimize". Deducing from this study, we are able to conclude by spoken language that additional is required to confirm that teaching and learning happen effectively despite the pandemic. that's regarding fashioning ways on however faculties will navigate through this crisis by victimization the strategy if introduce, sustain and optimize as mentioned within the literature review.

\section{Conclusions and Recommendations}

This study aimed at enlightening how the Covid-19 pandemic has degraded the inequities in the education fraternity by looking at how children and families access resources, whether or not they have supportive and safe environments that are necessary for optimal learning knowing that inequities are exponentially greater in times of crisis and suggest strategies to unravel the inequities to advocate for equal distribution and access of needs for all in academia. Literature was reviewed and analysed by searching the Google Scholar database. The following keywords were used in the search: Covid-19, educational inequities, education, horizontal and vertical equities, and myriad. The study revealed that family crises, lack of 
healthcare, mental health issues, poor technological instructions such as internet connectivity and computers, and poverty are one of the many challenges of educational inequities signalling as constraints to online learning in the Covid-19 pandemic. To mitigate these, this study recommends the following;

- With regards to internet connectivity the enhancement of the connection may be done by the government partnering with Internet Service Providers to install VSATs at the unreached areas. Secondly, the government can advise or encourage the mobile network operators that are MTC and Telecom to extend their coverage (which must include $3 \mathrm{G}$ and $4 \mathrm{G}$ ) to remote areas. This strategy should be backed with the provision of an adequate legal framework and security by the government for the protection of those installations and the Namibian people.

- the ministry of education should ensure an adequate supply of ICT facilities in needy schools and compulsory computer training for all the teachers and students.

- The government should fund a one-home-one-device initiative. This is to ensure that every home has access to an internet-enabled device, radio, or television for them to continue to have access to sexual and reproductive health education and counselling without face-to-face appointments. In addition, the government can employ health educators and computer trainers/facilitators in each village.

- One way of tackling harsh cultural practices that undermine school enrolment and indifference to ICT utilization is awareness creation among the parents, traditional and religious leaders on the importance of education. This could make them embrace change.

- The schools should also devise strategies of innovating, sustain and optimizing to unravel the inequities in academia.

\section{Acknowledgements}

We would like to thank our almighty God for being the driver as we wrote this paper and for keeping us in good health. Moreover, we extend our major appreciation to the International Journal for Research Publications for accepting our manuscript for publication. This is a milestone and we are grateful.

\section{References}

Africa Educational Trust. (2020). Our Working Somalia (retrieved from https://africaeducationaltrust.org/somalia/). 
Atchison, B., Diffey, L., Rafa, A., \& Sarubbi, M. (2017, June). Equity in Education: Key Questions to Consider. Education Commission of the States, pp. 1-6.

Baker, B. D., \& Green, P. C. (2015). Conceptions of equity and adequacy in school finance. In H. F. Ladd \& M. E. Goertz (Eds.), Handbook of research in education finance and policy (2nd ed., pp. 231-243). New York, NY: Routledge.

Business Wire. (2019). Somalia Telecoms, Mobile And Broadband Statistics And Analyses Report 2019.November 15 (retrieved from https://www.businesswire.com/news/home/20191115005357/en/Somalia-Telecoms-MobileBroadband-Statistics-Analyses-Report).

Chu, Y. (2019). What are they talking about when they talk about equity? A content analysis of equity principles and provisions in state Every Student Succeeds Act plans. education policy analysis archives, 27, 158.

Cook-Harvey, C. M., Darling-Hammond, L., Lam, L., Mercer, C., \& Roc, M. (2016). Equity and ESSA: Leveraging educational opportunity through every Student Succeeds Act. Palo Alto, CA: Learning Policy Institute. Retrieved from https://learningpolicyinstitute.org/product/equity-essa-report

Fuku, R., \& Hirsi, H. (2018). Improved Internet Access Connects Somali Students to Each Other and Global Knowledge (retrieved from https://blogs.worldbank.org/digital-development/improved-internetaccess-connects-somali-students-each-other-and-global-knowledge).

Fuku, R., \& Husseini, B. (2020). Keeping Students Connected in Somalia (retrieved from https://blogs.worldbank.org/digital-development/keeping-students-connected-somalia).

Gorard, S., \& Smith, E. (2004). An international comparison of equity in education systems. School Comparative Education,40(1), pp. 15-28.

Huber, S. G. (2019). Zerreißprobe oder klare Strategie? Schulentwicklung in der Balance von Bewahren, Optimieren, Innovieren. b:sl Beruf Schulleitung. Allgemeiner Schulleitungsverband Deutschlands e.V. (ASD) (Hrsg.). 4, 14. Jahrgang, 13-16.

Huber, S. G. (2020). Responsible Leaders entwickeln Schule in der Balance von Bewahren, Optimieren, Innovieren. In S. G. Huber (Hrsg.), Jahrbuch Schulleitung 2020. Impulse aus Wissenschaft und Praxis (S. 3-14). Köln: Wolters Kluwer Deutschland. 
Huber, S. G. (2021). Schooling and Education in Times of the COVID-19 Pandemic: Food for Thought and Reflection Derived From Results of the School Barometer in Germany, Austria and Switzerland. International Studies in Educational Administration (Commonwealth Council for Educational Administration \& Management (CCEAM)), 49(1).

Ismail, S. (2015). Equity and Education. International Encyclopedia of the Social \& Behavioural Sciences, Second Edition, 7, 918-923.

Knight, D. S. (2017). Are high-poverty school districts disproportionately impacted by state funding cuts? School finance equity following the great recession. Journal of Education Finance, 43(2), 169-194.

Knight, D. S. (2019). Are school districts allocating resources equitably? The Every Student Succeeds Act, teacher experience gaps, and equitable resource allocation. Educational Policy, 33(4), 615-649. https://doi.org/10.1177/0895904817719523

Lighting Africa. (2020). Somalia: Energy for prosperity (retrieved from https://www.lightingafrica.org/country/somalia-2/)

Martinez, J. A., \& Broemmel, A. D. (2021). Pencils down: Educators respond to the uncertainty amidst COVID-19 school closures. Int. Stud. Educ. Adm.(Commonw. Counc. Educ. Adm. Manag.(CCEAM)), 49, 109-132.

Mumin, A. A. (2018). Life at the bottom of the global league of internet access. The Guardian, October 18, 2020 (retrieved from https://amp.theguardian.com/technology/2018/oct/18/life-at-the-bottom-of-theglobal-league-of-internet-access).

Mwanjisi, J. (2020). COVID-19: School closures put decades of gains for somali children at risk (retrieved from https://www.savethechildren.net/blog/covid-19-school-closures-put-decades-gains-somalichildren-risk).

OECD Observer Staff (2008, January). Ten Steps to Equity in Education. Organization for Economic Cooperation and Development, pp. 1-8.

Omer, M., Klomsri, T., Tedre, M., Popova, I., Klingberg-Allvin, M,. \& Osman, F. (2015). E-learning opens door to the global community: Novice users' experiences of e-learning in a Somali University. MERLOT Journal of Online Learning and Teaching, 11(2), 267-279. 
Pollock, K. (2020). School Leaders' Work During the COVID-19 Pandemic: A Two-Pronged Approach. International Studies in Education, 48(3), 38-44.

Popa, S. (2020). Reflections on COVID-19 and the future of education and learning. Prospects, 1-6.

Soika, B. (n.d.). Economic Equity: Ensuring all Students Get the Resources They Need. USCrossier. https://rossier.usc.edu/economic-equity-ensuring-all-students-get-the-resources-they-need/

Ugwu, N. F. (2021). E-Option for Health Education Amidst COVID-19: An Examination of Somalia Contexts. CCEAM, 86.

UNESCO (2020). \#LearningNeverStops. COVID-19 education response. Paris: UNESCO. https://en.unesco.org/covid19/educationresponse/globalcoalition.

United Nations International Children's Emergency Fund [UNICEF]. (2020). Somalia Education (retrieved from https://www.unicef.org/somalia/education)

Verstegen, D. A. (2015). On doing an analysis of equity and closing the opportunity gap. Education Policy Analysis Archives, 23(41), 1-16. https://doi.org/10.14507/epaa.v23.1809

World Economic Forum (2019, September 24). We're all in the same boat on the SDGs: Here's how we steer a course. https://www.weforum.org/agenda/2019/09/sdg-fnancing-sustainable-development-impactsummi t-sailing/. 